\title{
Mass transfer and microbiological profile of pork meat dehydrated in two different osmotic solutions
}

\author{
Vladimir S. Filipović ${ }^{1}$, Biljana Lj. Ćurčić ${ }^{1}$, Milica R. Nićetin ${ }^{1}$, Dragana V. Plavšić ${ }^{2}$, Gordana B. Koprivica ${ }^{1}$, \\ Nevena M. Mišljenović ${ }^{1}$ \\ ${ }^{1}$ University of Novi Sad, Faculty of Technology, Novi Sad, Serbia \\ ${ }^{2}$ University of Novi Sad, Institute for Food Technology, Novi Sad, Serbia
}

\begin{abstract}
The effects of osmotic dehydration on mass transfer properties and microbiological profile were investigated in order to determine the usefulness of this technique as pre-treatment for further treatment of meat. The process was studied in two solutions (sugar beet molasses, and aqueous solution of sodium chloride and sucrose), at two temperatures (4 and $22{ }^{\circ} \mathrm{C}$ ) at atmospheric pressure. The most significant parameters of mass transfer were determined after $300 \mathrm{~min}$ of the dehydration. The water activity $\left(a_{\mathrm{w}}\right)$ values of the processed meat were determined, as well as the change of the microbiological profile between the fresh and dehydrated meat. At the temperature of $22{ }^{\circ} \mathrm{C}$ the sugar beet molasses proved to be the most suitable as an osmotic solution, despite the greater viscosity.
\end{abstract}

Keywords: osmotic dehydration; pork meat from shoulder blade; mass transfer; sugar beet molasses; microbiological profile.

\author{
SCIENTIFIC PAPER \\ UDC 66.093.48:637.564
}

Hem. Ind. 66 (5) 743-748 (2012)

doi: 10.2298/HEMIND120130033F

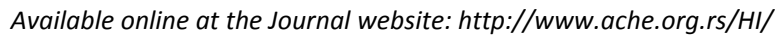

Water is one of the main constituents of fresh meat and plays a key role in many aspects related with its physicochemical, sensory and technological properties [1].

Many traditional techniques and their combinations, such as salting, drying, cooking, smoking and marinating, are used to prevent spoilage of meat and its products by reducing water content. A common step in these processes is placing product (meat) in contact with a concentrated solution (salt, sugar, acids, seasonings, etc.) [2].

Osmotic dehydration (OD) is an environmentally acceptable, material gentle drying method, which received considerable attention due to the low processing temperature, waste material and low energy requirement $[3,4]$.

$\mathrm{OD}$ is a water removal process, based on soaking food (fruit, vegetable, meat and fish) in a hypertonic solution. In comparison to other drying treatments main advantages of OD process are water is removed in liquid form, at mild temperatures and osmotic solution can be reused $[5,6]$.

Recent research has shown that use of sugar beet molasses as a hypertonic solution improves OD processes [7]. Sugar beet molasses proved to be excellent as the OD medium due to the high dry matter (80\%) and specific nutrient content. Using sugar beet molas-

Correspondence: V.S. Filipović, University of Novi Sad, Faculty of Technology, Bulevar cara Lazara 1, 21000 Novi Sad, Serbia.

E-mail: vladaf@uns.ac.rs

Paper received: 30 January, 2012

Paper accepted: 20 March, 2012 ses as hypertonic solution is an important part of the food material enrichment in minerals and vitamins, which penetrate from molasses into the plant tissue $[8,9]$. The presence of complex solute compositions maintains a high transfer potential favorable to water loss, and at the same time by the presence of sugar, salt impregnation is hindered [10]. High salt concentrations decrease the water holding capacity, which contributes to meat dehydration and shrinkage while there is no swelling of muscle fibers or myofibrils [11,12].

Due to its nature as perishable food product, it is important to appropriately store, process, package, and distribute meat as it spoils quickly and becomes hazardous due to microbial growth. Microbial meat contamination is mostly influenced by the conditions prior and subsequent to animal slaughter, meat handling, as well as storage conditions [13].

In literature, although there is a lot of information about OD of plant material, but there is a little information available about OD of meat and none about OD of meat in molasses. Preliminary sensory analysis has shown that meat processed in this manner had satisfactory sensory characteristics.

By processing pork meat from the shoulder blade by means of $O D$, the initial microbiological profile of the pork meat should be improved due to increasing dry matter content and lowered $a_{\mathrm{w}}$ value of the processed meat.

The objective of this research was to examine the influence of two different osmotic solutions at two different temperatures on the efficiency of OD process characterized by mass transfer and microbiological pro- 
file of the fresh pork meat as a validation of the process efficiency and safety.

\section{EXPERIMENTAL}

Fresh pork meat from the shoulder blade was purchased at the local butcher shop in Novi Sad, shortly prior to the experiment. The initial moisture content of the fresh meat was $72.83 \%$. Prior to the treatment, all working areas and tools were thoroughly washed, cleaned and disinfected with pharmaceutical ethanol (70 vol.\%). Fresh meat was cut into cubes dimension of approximately $1 \mathrm{~cm} \times 1 \mathrm{~cm} \times 1 \mathrm{~cm}$. An aqueous osmotic solution (AOS) of sodium chloride and sucrose was made from commercial sucrose and $\mathrm{NaCl}$ in the quantities of 1200 and $350 \mathrm{~g} / \mathrm{kg}$ of distilled water, respectively. Sugar beet molasses was obtained from the sugar factory Pećinci, Serbia. The initial dry matter content in sugar beet molasses was $85.04 \%$. In all experiments, a weight ratio of solution to meat sample of $5: 1$ was used, which can be considered high enough to neglect the concentration changes during the process. Every 15 $\mathrm{min}$, the meat samples in osmotic solutions were stirred to remove quantities of water that diffused from the center of the meat cube to its surface and allowing better homogenization of the osmotic solutions. The conditions of homogenization (intensity, duration and frequency of stirring) were the same for both osmotic solutions at both temperatures, so the results could be comparable.

The experiments were conducted under atmospheric pressure at temperatures of 4 and $22^{\circ} \mathrm{C}$, during $5 \mathrm{~h}$. After the process of $\mathrm{OD}$, the meat samples were washed with sterilized water and gently blotted to remove excessive water. The meat samples were weighed and part of the samples were kept in an oven (Instrumentaria Sutjeska, Croatia) at $105{ }^{\circ} \mathrm{C}$ until constant weight was attained, and dry matter content calculated from the samples weights before and after drying. Values of dry matter content (DMC), water loss (WL), and solid gain (SG) were calculated as described by Mišljenović et al. [14], and presented as a mean value and standard deviation of 6 parallel runs.
Viscosities of both osmotic solutions, prior and after the process of OD and at both temperatures was measured by an Oswald viscosimeter. The values of molasses viscosity were out of reach of the method's range. Literature data [15] was cited.

Analysis of variance (ANOVA) was performed using StatSoft Statistica v10 for Windows software.

Water activity $\left(a_{\mathrm{w}}\right)$ of the osmotically dehydrated samples was measured using a water activity measurement device (TESTO 650, Germany) with an accuracy of \pm 0.001 at $25^{\circ} \mathrm{C}$.

Determination of the Salmonella spp., Escherichia coli, the total number of bacteria and Enterobacteriaceae was done by the SRPS EN ISO 6579 [16]; SRPS ISO 16649-2 [17]; SRPS EN ISO 4833 [18] and the SRPS ISO 21528-2 [19], respectively.

\section{RESULTS AND DISCUSSION}

Based on mass transfer and microbiological profile, the efficiency of the OD process in different osmotic solutions and at different temperatures of the meat was evaluated.

DMC of the fresh pork meat was $26.20 \pm 1.67 \%$, and the results of the DMC obtained in the process of OD were varying from $52.85 \pm 1.76$ to $56.38 \pm 0.83 \%$. The data of the WL obtained in the process of OD of the pork meat were between $0.3590 \pm 0.0042$ and $0.4261 \pm$ $\pm 0.0145 \mathrm{~g} / \mathrm{g}$ i.s (Table 1 ).

ANOVA has showed the same trends for the examined values of DMC and WL. There was no significant statistical difference $(p<0.05)$ between values of DMC or WL of the meat dehydrated in AOS at $4{ }^{\circ} \mathrm{C}$ and the meat dehydrated in molasses at $4{ }^{\circ} \mathrm{C}$. Also, there was no significant statistical difference between value of DMC or WL of the meat dehydrated in AOS at $22{ }^{\circ} \mathrm{C}$ and the meat dehydrated in molasses at $22{ }^{\circ} \mathrm{C}$, but there was significant statistical difference between values of DMC or WL in meats dehydrated in the same osmotic solution but at different temperatures.

This indicates that temperature has a significant influence, while the nature of the osmotic solution does not have a significant influence on the DMC or WL of the osmotically dehydrated meat.

Table 1. Average values and standard deviations of dry matter content (DMC), water loss (WL), solid grain (SG) and WL/SG ratio of the dehydrated meat

\begin{tabular}{lccccccc}
\hline Parameter & Fresh meat & & \multicolumn{2}{c}{ Meat dehydrated in AOS } & & \multicolumn{2}{c}{ Meat dehydrated in molasses } \\
\cline { 1 - 4 } \cline { 5 - 7 } Temperature of the process, ${ }^{\circ} \mathrm{C}$ & - & 4 & 22 & & 4 & 22 \\
Dry matter content, \% & $26.20 \pm 1.67^{\mathrm{a}}$ & $52.97 \pm 0.64^{\mathrm{b}}$ & $55.73 \pm 1.02^{\mathrm{c}}$ & & $52.85 \pm 1.76^{\mathrm{b}}$ & $56.38 \pm 0.83^{\mathrm{c}}$ \\
Water loss*, g/g i.s. & - & & $0.3739 \pm 0.0084^{\mathrm{a}}$ & $0.4261 \pm 0.0145^{\mathrm{b}}$ & & $0.3590 \pm 0.0042^{\mathrm{a}}$ & $0.4212 \pm 0.0182^{\mathrm{b}}$ \\
Solid gain*, g/g i.s. & - & & $0.1239 \pm 0.0211^{\mathrm{a}}$ & $0.1348 \pm 0.0074^{\mathrm{a}}$ & & $0.1341 \pm 0.0328^{\mathrm{a}}$ & $0.1329 \pm 0.0141^{\mathrm{a}}$ \\
WL/SG ratio & - & & $2.86 \pm 0.71$ & $2.98 \pm 0.81$ & & $3.16 \pm 0.16$ & $3.43 \pm 0.42$ \\
\hline
\end{tabular}

${ }^{\mathrm{abc}}$ Different letters in the superscript in the same row indicate significant statistical difference between the values, at level of significance $p<0.05$; *mass in grams of WL or SG per mass in grams of initial sample 
Values of the SG in the pork meat after the OD were similar regardless of the osmotic solutions and temperatures, and varied from $0.1239 \pm 0.0211$ to $0.1348 \pm$ $\pm 0.0074 \mathrm{~g} / \mathrm{g}$ i.s. ANOVA has showed that there was no significant statistical difference between values of SG in any sample of dehydrated meats.

From the results for DMC, WL and SG for meat dehydrated in the AOS at $22{ }^{\circ} \mathrm{C}$ and molasses at $22^{\circ} \mathrm{C}$, the slight inconsistency of the material balance is evident (mean value of the DMC for the meat dehydrated in AOS at $22{ }^{\circ} \mathrm{C}$ is lower than the value of DMC for the meat dehydrated in molasses at $22{ }^{\circ} \mathrm{C}$, while $\mathrm{WL}$ and SG mean values are higher for the meat dehydrated in AOS than in molasses). The jnconsistency may be the result of the grouping of series of individual values of DMC, WL and SG, from which mean values and standard deviations were derived. By paring mean values of these parameters, slight inconsistency occurs which is noticeable from the difference of the third decimals of WL and SG.

The efficiency of process of the OD was evaluated according to the ratio of WL/SG. Higher values indicate that the process is characterized by higher $\mathrm{WL}$ and lower SG, which are favorable. The data presented in Table 1 shows that higher temperatures of the process positively contribute to higher WL/SG ratio in AOS and molasses (WL/SG of $2.98 \pm 0.81$ at $22^{\circ} \mathrm{C}$ in comparison to $2.86 \pm 0.71$ at $4{ }^{\circ} \mathrm{C}$ in AOS, and $3.43 \pm 0.42$ at $22{ }^{\circ} \mathrm{C}$ in comparison to $3.16 \pm 0.16$ at $4{ }^{\circ} \mathrm{C}$ in molasses). Also, the meat dehydrated in molasses had higher WL/SG ratios at the corresponding temperatures in comparison to the meat dehydrated in AOS.

Values of viscosity of the osmotic solutions prior and after OD at both temperatures are shown in Table 2. Values of viscosity of osmotic solutions are highly influenced by temperature, dilution due to the water diffusing from the meat during the process of $O D$ and nature of the osmotic solution. Values of viscosity for the molasses were much higher (even out of range of the applied method of determination) at both temperatures than the values of viscosity of $A O S$. The reduction of viscosity of the molasses after the process of OD is much greater than the reduction of the viscosity of the AOS (approximately 100 times for molasses, and 2.3 to 2.5 times for AOS).

The average $a_{\mathrm{w}}$ values and standard deviation of the fresh and dehydrated meat in AOS and molasses at $4{ }^{\circ} \mathrm{C}$ and $22{ }^{\circ} \mathrm{C}$ are shown in Table 3. Start value of the fresh meat was $0.936 \pm 0.01$. It is obvious that process of osmotic dehydration lowered the $a_{\mathrm{w}}$ values of the meat. Meat dehydrated in AOS achieved lower $a_{\mathrm{w}}$ values $\left(0.850 \pm 0.003\right.$ and $0.841 \pm 0.004$ at 4 and $22{ }^{\circ} \mathrm{C}$, respectively) in comparison to the meat dehydrated in molasses $\left(0.875 \pm 0.025\right.$ and $0.871 \pm 0.031$ at 4 and $22{ }^{\circ} \mathrm{C}$, respectively). Increase of the temperature exerted positive influence on the lowering $a_{\mathrm{w}}$ value of the meat dehydrated in both osmotic solutions.

Very complex composition of molasses, which via solid gain is incorporated in the dehydrated meat, has changed chemical composition of dehydrated meat in much greater extent than the chemical composition of dehydrated meat in AOS. Activity of the present water in dehydrated meat is affected by this complex composition [20], and leads to the inconsistency of the $a_{w}$ values of meat dehydrated in molasses in comparison to the meat dehydrated in AOS at both temperatures.

Achieved $a_{\mathrm{w}}$ values of the meat dehydrated in both osmotic solutions were lower than $a_{\mathrm{w}}$ values that inhibit growth of the most microorganisms except molds [21].

Microbiological analysis of the fresh and dehydrated meat is presented in Table 4 . None of the analyzed samples showed traces of Salmonella spp. This indicates that the produced dehydrated semi-product from meat is in accordance with the requirements for food safety criteria of the Serbian National Regulation [22].

The total number of bacteria in the fresh meat cut and prepared for the osmotic dehydration in laboratory was $466667 \pm 57735 \mathrm{CFU} / \mathrm{g}$ (Table 4).

ANOVA has showed that there was significant statistical difference between the total number of bacteria in all dehydrated meats and the fresh meat, but there was no significant statistical difference between the total number of bacteria in the meat dehydrated in both osmotic solutions and at both temperatures of the process. This indicates that the process of OD has a significant influence on lowering total number of bacteria in the osmotically dehydrated meat.

Temperature of the process of $4{ }^{\circ} \mathrm{C}$ has contributed to the higher reduction of the total number of bacteria in the dehydrated meat in AOS, while in case of dehydration meat in molasses, the higher reduction of the total number of bacteria was achieved at the temperature of the process of $22{ }^{\circ} \mathrm{C}$, probably due to the

Table 2. Viscosities of the osmotic solutions (Pa s)

\begin{tabular}{|c|c|c|c|c|c|c|c|}
\hline \multicolumn{4}{|c|}{ AOS } & \multicolumn{4}{|c|}{ Molasses } \\
\hline \multicolumn{2}{|c|}{ Prior OD } & \multicolumn{2}{|c|}{ After OD } & \multicolumn{2}{|c|}{ Prior OD } & \multicolumn{2}{|c|}{ After OD } \\
\hline \multicolumn{8}{|c|}{ Temperature of the process, ${ }^{\circ} \mathrm{C}$} \\
\hline 4 & 22 & 4 & 22 & 4 & 22 & 4 & 22 \\
\hline 0.7179 & 0.3795 & 0.3080 & 0.1482 & $-^{a}$ & $400^{b}$ & 12.3418 & 4.0486 \\
\hline
\end{tabular}

${ }^{\mathrm{a}}$ No literature data for the viscosity of the molasses at the temperatures below $10^{\circ} \mathrm{C} ;{ }^{\mathrm{b}}$ literature data [15] 
much higher viscosity of the molasses at the lower temperatures [23], Table 2, which allowed extended retention of the transferred water from the center of the meat sample to its surface.

Table 3. Average water activity $\left(a_{w}\right)$ values and standard deviation of the fresh and dehydrated meat at two temperatures

\begin{tabular}{lcc}
\hline \multirow{2}{*}{ Sample } & \multicolumn{2}{c}{ Temperature of the OD, ${ }^{\circ} \mathrm{C}$} \\
\cline { 2 - 3 } & \multicolumn{2}{c}{42} \\
\hline Fresh meat & \multicolumn{2}{c}{$0.936 \pm 0.01$} \\
Meat dehydrated in AOS & $0.850 \pm 0.003$ & $0.841 \pm 0.004$ \\
Meat dehydrated in molasses & $0.875 \pm 0.025$ & $0.871 \pm 0.031$ \\
\hline
\end{tabular}

The number of Enterobacteriaceae in the fresh meat was $14333 \pm 577 \mathrm{CFU} / \mathrm{g}$ (Table 4) but after the process of OD it was lowered in all samples dehydrated in both osmotic solutions. The reductions of the numbers of Enterobacteriaceae in dehydrated samples in comparison to the initial number of Enterobacteriaceae in the fresh meat were 90.70, 98.60, 91.86 and $98.83 \%$ for samples dehydrated in AOS at $4{ }^{\circ} \mathrm{C}, \mathrm{AOS}$ at $22{ }^{\circ} \mathrm{C}$, molasses at $4{ }^{\circ} \mathrm{C}$ and molasses at $22{ }^{\circ} \mathrm{C}$, respectively.

ANOVA has showed that there was no significant statistical difference between the number of Enterobacteriaceae of the meat dehydrated in AOS at $4{ }^{\circ} \mathrm{C}$ and the meat dehydrated in molasses at $4{ }^{\circ} \mathrm{C}$. Also, there was no significant statistical difference between the number of Enterobacteriaceae of the meat dehydrated in $\mathrm{AOS}$ at $22{ }^{\circ} \mathrm{C}$ and the meat dehydrated in molasses at $22{ }^{\circ} \mathrm{C}$, but there was significant statistical difference in the number of Enterobacteriaceae in meat dehydrated in the same osmotic solution but at the different temperatures. This indicates that temperature has a significant influence, while the nature of the osmotic solution does not have a significant influence on the reduction of the number of Enterobacteriaceae in the osmotically dehydrated meat.

The Serbian National Regulation [21] does not determine reference values for the total number of bacteria or number of Enterobacteriaceae for the meat pieces, but by tracking the change of these parameters it can indicate the level of hygiene of the process and the sustainability of the produced semi product. The results of the reduction of total number of bacteria and number of Enterobacteriaceae in any dehydrated meat in comparison to the fresh meat indicate that the process of $O D$ is hygienically safe.

The number of Escherichia coli in the fresh meat cut and prepared for the osmotic dehydration in laboratory was $130 \pm 26 \mathrm{CFU} / \mathrm{g}$ (Table 3). After the process of OD, the number of Escherichia coli in the dehydrated meat was lowered in samples dehydrated in both osmotic solutions. ANOVA has showed the same trends of statistical significance in analysis of the number of Escherichia coli, as in the analysis of the number of Enterobacteriaceae, so it indicates that temperature has a significant influence, while the nature of the osmotic solution does not have a significant influence on the reduction of the number of Escherichia coli in the osmotically dehydrated meat.

The reductions of the numbers of Escherichia coli in dehydrated samples in comparison to the fresh meat were $63.85,100,71.54$ and $100 \%$ for samples dehydrated in AOS at $4{ }^{\circ} \mathrm{C}, \mathrm{AOS}$ at $22^{\circ} \mathrm{C}$, molasses at $4{ }^{\circ} \mathrm{C}$ and molasses at $22{ }^{\circ} \mathrm{C}$, respectively. Achieved values of the number of Escherichia coli in all samples from the dehydrated meats are negligible in comparison to the determined values and are in accordance with the hygiene production criteria of the Serbian National Regulation [21].

\section{CONCLUSION}

The data presented in this research indicate that higher temperature of the process of the OD contributes to better results of the technological parameters of dehydrated meat (DMC, WL and WL/SG). Superior results of the technological parameters were obtained in the process of OD of meat in molasses in comparison to the AOS.

Achieved $a_{\mathrm{w}}$ values of dehydrated meat indicate that growth of microorganisms in that environment

Table 4. Microbiological analysis of the fresh and dehydrated meat at different temperatures (average numbers and standard deviation)

\begin{tabular}{|c|c|c|c|c|c|}
\hline \multirow{2}{*}{$\begin{array}{l}\text { Parameter } \\
\text { Temperature of the process, }{ }^{\circ} \mathrm{C}\end{array}$} & \multirow{2}{*}{$\begin{array}{c}\text { Fresh meat cut in } \\
\text { laboratory } \\
-\end{array}$} & \multicolumn{2}{|c|}{ Dehydrated meat in AOS } & \multicolumn{2}{|c|}{ Dehydrated meat in molasses } \\
\hline & & 4 & 22 & 4 & 22 \\
\hline \multicolumn{6}{|c|}{ Food safety criteria } \\
\hline Salmonella spp. (negative/10 g) & $0 \pm 0^{\mathrm{a}}$ & $0 \pm 0^{a}$ & $0 \pm 0^{\mathrm{a}}$ & $0 \pm 0^{\mathrm{a}}$ & $0 \pm 0^{\mathrm{a}}$ \\
\hline \multicolumn{6}{|c|}{ Production hygiene criteria } \\
\hline Total number of bacteria, CFU/g & $466667 \pm 57735^{a}$ & $183333 \pm 57735^{\mathrm{b}}$ & $216667 \pm 76376^{\mathrm{b}}$ & $183333 \pm 28867^{b}$ & $116667 \pm 28867^{b}$ \\
\hline Enterobacteriaceae, CFU/g & $14333 \pm 577^{\mathrm{a}}$ & $1333 \pm 577^{b}$ & $200 \pm 100^{c}$ & $1167 \pm 289^{b}$ & $167 \pm 115^{c}$ \\
\hline Escherichia coli, CFU/g & $130 \pm 26^{\mathrm{a}}$ & $47 \pm 6^{b}$ & $0 \pm 0^{c}$ & $37 \pm 6^{\mathrm{b}}$ & $0 \pm 0^{c}$ \\
\hline
\end{tabular}


would be inhibited. Results of the microbiological analysis of the fresh and dehydrated pork meat confirmed the assumption made on the basis of measured $a_{\mathrm{w}}$ values.

OD of meat in molasses contributed to better reduction of the present microorganisms in fresh pork meat in comparison to the OD of meat in the AOS at the corresponding temperatures.

Dehydrated pork meat in molasses experienced higher reduction of the present microorganisms from the fresh meat at temperature of $22{ }^{\circ} \mathrm{C}$, probably due to the high viscosity of the molasses at temperature of $4{ }^{\circ} \mathrm{C}$.

The microbiological profile of the osmotically dehydrated meat has shown that the OD is hygienically safe process and semi products are safe for further technological production.

OD of the fresh pork meat in molasses as osmotic solution at the temperature of $22{ }^{\circ} \mathrm{C}$ has contributed to the better technological and microbiological parameters in comparison to the process at the temperature of $4{ }^{\circ} \mathrm{C}$, without the need of extra input of energy. OD, as an environmentally acceptable process, contributes to the extended usage of the by-product of sugar beet production.

\section{Acknowledgement}

These results are part of project supported by the Ministry of Education, Science and Technological Development of the Republic of Serbia, TR-31055.

\section{REFERENCES}

[1] R.A. Lawrie, Meat Science (fourth ed.), Pergamon Press, Oxford, 1985, 138-158.

[2] A. Collignan, P. Bohuon, F. Deumier, I. Poligne, Osmotic treatment of fish and meat products. J. Food Eng. 49 (2001) 153-162.

[3] N.M. Panagiotou, V.T. Karanthanos, Z.B. Maroulis, Effect of osmotic agent on osmotic dehydration of fruits. Dry Technol. 17 (1999) 175-189.

[4] K.N. Waliszewiski, H.D. Cortez, V.T. Pardio, M.A. Garcia, Color parameter changes in banana slices during osmotic dehydration. Dry Technol. 17 (1999) 955-960.

[5] M. Della Rosa, F. Giroux, Osmotic treatments (OT) and problems related to the solution management. J. Food Eng. 49 (2001) 223-236.

[6] D. Torreggiani, Osmotic dehydration in fruit and vegetable processing. Food Res. Int. 26 (1993) 59-68.

[7] G. Koprivica, N. Mišljenović, Lj. Lević, T. Kuljanin, Influence of nutrients present in sugar beet molasses and saccharose solution on the quality of osmodehydrated carrot. Journal on Processing and Energy in Agriculture, 13 (2009) 178-180.

[8] G. Koprivica, N. Mišljenović, Lj. Lević, M. Petkova, V. Pribiš, Osmotic dehydration of apple in sucrose and sugar beet molasses: Change of nutritive properties of final product, Journal on Processing and Energy in Agriculture 12 (2008) 215-218 (In Serbian).

[9] G. Koprivica, N. Misljenović, Lj. Lević, V. Pribiš, Changes in nutritive and textural quality of apple osmodehydrated in sugar beet molasses and saccharose solution. Acta Periodica Technologica 40 (2009) 35-46.

[10] S.J. Santchurn, A. Collignan, G. Trystram, Impact of solute molecular mass and molality, and solution viscosity on mass transfer during immersion of meat in a complex solution. J. Food Eng. 78 (2007) 1188-1201.

[11] J. Barat, M. Alino, A. Fuentes, R. Grau, J. B. Romero, Measurement of swelling pressure in pork meat brining. J. Food Eng. 93 (2009) 108-113.

[12] M. Aliñoa, R. Grau, A. Fernández-Sánchez, A. Arnold, J.M. Barat, Influence of brine concentration on swelling pressure of pork meat throughout salting. Meat Science 86 (2010) 600-606.

[13] T.C. Jackson, M.D. Hardin, G.R. Acuff, Heat resistance of Escherichia coli 0157:H7 in a nutrient medium and in ground beef patties as influenced by storage and holding temperature. J. Food Prot. 59 (1997) 230-237.

[14] N. Mišljenović, G. Koprivica, Lj. Lević, Comparison of the kinetics of osmotic drying apples in sugar beet molasses and sucrose solutions, J. Process. Energy Agric. 14 (2010) 32-35.

[15] S. Šušić, S. Petrov, G. Kukić, V. Sinobad, P. Perunović, B. Koronsovac, Đ. Bašić, Fundamentals of Technology of Sugars, Industrija šećera Jugoslavije i Poslovno udruženje Jugošećer, Belgrade, 1994 (In Serbian).

[16] SRPS EN ISO 6579: Microbiology of food and animal feeding stuffs, Horizontal method for the detection of Salmonella spp. (2008).

[17] SRPS ISO 16649-2: Microbiology of food and animal feeding stuffs, Horizontal method for the enumeration of beta-glucuronidase-positive Escherichia coli, Part 2: Colony-count technique at 44 degrees $C$ using 5-bromo4-chloro-3-indolyl beta-D-glucuronide (2001).

[18] SRPS EN ISO 4833: Microbiology of food and animal feeding stuffs, Horizontal method for the enumeration of microorganisms, Colony-count technique at $30 \mathrm{de}$ grees C (2003).

[19] SRPS ISO 21528-2: Microbiology of food and animal feeding stuffs, Horizontal methods for the detection and enumeration of Enterobacteriaceae, Part 2: Colonycount method (2004).

[20] H. Olbrich: The Molasses, Fermentation Technologist, Institut für Zuckerindustrie, Berlin, Germany, 1963.

[21] Database of Physical Properties of Food, http:// //www.nelfood.com. 2012.

[22] Regulation of general and special conditions of food hygiene at any stage of production, processing and transport, Official Gazette of RS 72 (2010).

[23] Lj. Lević, V. Filipović, T. Kuljanin: Osmotic treatment of shaped carrot in sucrose and molasses, Časopis za procesnu tehniku i energetiku u poljoprivredi - PTEP, 11 (2007) 132-134. (In Serbian). 


\section{IZVOD}

\section{PRENOS MASE I MIKROBIOLOŠKI PROFIL OSMOTSKI DEHIDRIRANOG SVINJSKOG MESA U DVA RAZLIČITA RASTVORA}

Vladimir S. Filipović ${ }^{1}$, Biljana Lj. Ćurčić ${ }^{1}$, Milica R. Nićetin ${ }^{1}$, Dragana V. Plavšić ${ }^{2}$, Gordana B. Koprivica ${ }^{1}$, Nevena M. Mišljenović ${ }^{1}$

${ }^{1}$ Univerzitet u Novom Sadu, Tehnološki fakultet, Novi Sad, Srbija

${ }^{2}$ Univerzitet u Novom Sadu, Institut za prehrambene tehnologije, Novi Sad, Srbija

(Naučni rad)

Osmotska dehidratacija kao metod sušenja materijala je u poslednje vreme sve aktuelnija zbog karakteristika niske procesne temperature, niskih energetskih zahteva procesa kao i male količine otpadnog materijala. Osmotska dehidratacija je proces ukljanjanja vode iz materijala potapanjem sirovine $u$ hipertonične rastvore, gde je glavna prednost ovog procesa uklanjanje vode iz materijala u tečnoj fazi, pri umerenim temperaturama, kao i mogućnost ponovne upotrebe osmotskih rastvora. U ovom istraživanju ispitivani su uticaji procesa osmotske dehidratacaije na prenos mase i promenu mikrobiološkog profila s ciljem određivanja upotrebljivosti ove tehnike kao pred-tretmana u procesu obrade mesa. Proces je ispitivan u dva osmotska rastvora (melasa šećerne repe i vodeni rastvor natrijum hlorida i saharoze), na dve temperature $\left(4 \mathrm{i} 22^{\circ} \mathrm{C}\right)$ pri atmosferskom pritisku. Najznačajniji parametri prenosa mase su određeni nakon 300 min osmotske dehidratacije. Određene su i $a_{\mathrm{w}}$ vrednosti dehidriranog mesa kao i promena mikrobiološkog profila mesa nakon dehidratacije. Ispitivanjem je utvrđeno da temperatura ima značajan statistički uticaj, dok priroda osmotskog rastvora nema značajan statistički uticaj na sadržaj suve materije i gubitak vode iz mesa. Takođe je utvrđeno da nema značajne statističke razlike između vrednosti prirasta suve materije između ispitivanih uzoraka mesa. Postignute $a_{\mathrm{w}}$ vrednosti u dehidriranom mesu u oba osmotska rastvora su niže od graničnih $a_{\mathrm{w}}$ vrednosti koje inhibiraju rast većine mikroorganizama. Ispitivanjem promene mikrobiološkog profila mesa nakon osmotske dehidratacije utvrđeno je da dobijeni poluproizvodi od dehidriranog mesa zadovoljavaju kriterijume bezbednosti hrane i higijenske kriterijume definesane Pravilnikom o opštim i posebnim uslovima higijene hrane u bilo kojoj fazi proizvodnje, prerade i prometa (Službeni glasnik R.S., 72/2010). Bolji rezultati tehnoloških parametara i poboljšanja mikrobiološkog profila dobijeni se u procesu osmotske dehidratacije svinjskog mesa na temperaturi od $22{ }^{\circ} \mathrm{C}$ uz upotrebu melase šećerne repe kao osmotskog rastvora u poređenju sa vodenim rastvorom natrijum-hlorida i saharoze.

Ključne reči: Osmotska dehidratacija • Meso svinjske plećke - Prenos mase • Melasa šećerne repe • Mikrobiološki profil 